\title{
Vliv plyometrického tréninku (depth jump) na běžeckou a cyklistickou ekonomiku pohybu
}

\section{The effect of plyometric training (depth jump) on running economy and cycling economy}

\author{
Jiří Bílý', Jan Cacek', Tomáš Kalina', Akaninyene Arnold Sunday² \\ ${ }^{1}$ Fakulta sportovních studií Masarykovy univerzity, Brno \\ ${ }^{2}$ Faculty of Education, University of Calabar, Nigeria
}

\begin{abstract}
Abstrakt
Vytrvalostní sportovní výkon je ovlivňován mnoha faktory. Jedním z nich je ekonomika pohybu. Vnašem výzkumu se věnujeme ekonomice běžecké a cyklistické.

Účastníky výzkumu byli studenti prvního ročníku Fakulty sportovních studii Masarykovy univer-

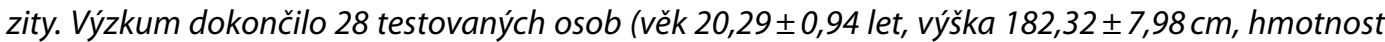
$76,98 \pm 10,03$ kg), které byly náhodně rozděleny do experimentální a kontrolní skupiny. Před tréninkovým programem i po něm probíhalo vstupní testování zaměřené na zjištování RE (ekonomika běhu) a CE (cyklistická ekonomika). Intervenční tréninkový program plyometrického charakteru trval 8 týdnů, probandi trénovali $2 \times$ v týdnu (8 sérií po 10 opakováních cviku depth jump v každém tréninku).

Výsledky ukázaly, že realizací krátkodobého plyometrického tréninku prostřednictvím cviku depth jump nedošlo k signifikantnímu zlepšení RE při běhu rychlostí 10 a $12 \mathrm{~km}$. hod. $^{-1}$ Stejně tak nedošlo k signifikantnímu zlepšení CE při zátěži $1,5 \mathrm{~W} \cdot \mathrm{kg}^{-1}$ a $2 \mathrm{~W} \cdot \mathrm{kg}^{-1}$. Z hlediska výstupů pro praxi nedoporučujeme při uvedených rychlostech a intenzitě šlapání aplikovat plyometrický trénink daného charakteru.
\end{abstract}

\section{Abstract}

Endurance sport performance is influenced by many factors, such as motor economies. In this research we focused on running and cycling economies.

Twenty-eight first year students of Faculty of Sport science of Masaryk University (age $20.29 \pm 0.94$ years, height $182.32 \pm 7.98 \mathrm{~cm}$, weight $76.98 \pm 10.03 \mathrm{~kg}$ ) were purposively selected to participate as subjects. The test subjects were randomized into experimental group $(n=17)$ and control group $(n=11)$. Pre-test and post-test were taken on RE and CE. The PI protocol was eight weeks, twice a week, eight sets per day, and ten repetitions per set.

The results showed that short-term plyometric training using depth jump had no significant effect on RE when running at 10 and $12 \mathrm{~km} \cdot \mathrm{h}^{-1}$. Likewise there was no significant effect on CE using strain of $1.5 \mathrm{~W} . \mathrm{kg}^{-1}$ and $2 \mathrm{~W} \cdot \mathrm{kg}^{-1}$. From the point of view of practical use we do not recommend apply analogous plyometric training using declared running speed and cycling intensity.

Klíčová slova: cyklus natažení a zkrácení, vertikální výskok.

Keywords: short stretch cycle, vertical jump.

\section{ÚVOD}

Sportovní výkon je ovlivňován mnoha faktory. Jedním z významných faktorů determinujících vytrvalost je ekonomika pohybu (Midgley, McNaughton \& Jones, 2007; Bassett \& Howley, 2000). Mezi další významné faktory patři např. maximální spotřeba kyslíku, přičemž někteří autoři uvádějí jako nejvýznamnější faktor právě ekonomiku pohybu (Saunders et al., 2004). 
Ekonomika vytrvalostního pohybu bývá vyjádřena spotřebou kyslíku $\left(\mathrm{ml} \mathrm{kg}^{-1} \cdot \mathrm{min} .^{-1}\right)$ při určité rychlosti běhu nebo určité zátěži na kole (Morgan, Martin \& Krahenbuhl, 1989; Grasgruber \& Cacek, 2008). Saunders et al. (2004) definují ekonomiku běhu (RE) jako energetickou náročnost pro danou submaximální rychlost běhu, která je měřena v ustáleném stavu spotřeby kyslíku a poměru respirační výměny. Mezi determinanty ekonomiky běhu podle Grasgrubera a Cacka (2008) patří faktory fyziologické, somatické, endogenní a technika běhu. Další rozdělení determinant ekonomiky běhu popisuje Saunders et al. (2004), který mezi ně řadí trénink, vnější prostředí, fyziologické faktory, biomechanické faktory a antropometrické parametry.

V našem výzkumu se budeme zabývat vlivem aplikace plyometrie (jedna z metod rozvoje explozivní síly) na ekonomiku pohybu. Prostřednictvím této metody lze pozitivně působit na schopnost využití elastické energie protahovacího reflexu (koncentrické svalové činnosti vždy předchází excentrické protažení svalu) a velice účinně stimulovat nervové faktory podmiňující rychlost vyvinutí síly (Cacek, Lajkeb \& Michálek, 2007). Plyometrický cyklus, tzv. cyklus natažení a zkrácení (SSC), obsahuje 3 fáze: protažení svalu (excentrická kontrakce), přechodová fáze (amortizační fáze) a zkrácení svalu (koncentrická kontrakce) (Psotta, 2006). Přechodová fáze by měla trvat maximálně 150 až 200 ms, aby se uplatnil cyklus natažení a zkrácení svalového vlákna, a šlo tak o plyometrické cvičení. Kdyby trvala přechodová fáze déle, došlo by ke ztrátě elastické energie (Kampmiller et al., 2012). Otázkou zůstává, jaké jsou limity využití plyometrických intervencí pro maximalizaci vytrvalostních výkonů odlišného charakteru. Jedním z limitů by mohl být výběr cvičení z hlediska specifičnosti (koordinační, metabolická a mechanická shoda se soutěžním výkonem). V naší studii sledujeme vliv jednoho z nejčastěji využivaných plyometrických cviků - snožný vertikální výskok po seskoku z vyvýšené podložky (depth jump). Další omezení efektu může být dáno designem plyometrické intervence. Zejména potom manipulovatelné proměnné (objem, frekvence, intenzita, doba zotavení aj.) mohou významně ovlivnit účinnost plyometrické metody.

\section{Depth jump}

Plyometrický cvik depth jump představuje jeden z nejčastěji uživaných prostředků plyometrického tréninku. Testovaná osoba stojí na lavičce, vykročením seskočí z lavičky a ihned po dopadu snožmo provede vertikální výskok. Doba kontaktu se zemí je co nejkratší a výskok co nejvyšší (proveden s maximální intenzitou) (Wang \& Zhang, 2016).

U skoků prováděných z vyvýšeného místa je důležitá výška předmětu, ze kterého se následně seskakuje. Nejčastěji se skoky provádějí z výšky $40 \mathrm{~cm}$ (Kijowksi et al., 2015; Markovic, Jukic, Milanovic \& Metikos, 2007). V některých odborných studiích zahrnujících depth jump se skáče stále ze stejné výšky. Např. Markovic, Jukic, Milanovic a Metikos (2007) používali výšku $40 \mathrm{~cm}$ s pauzou mezi skoky $5 \mathrm{~s}$. V jiných se kombinují různé výšky, často 20, 40 a $60 \mathrm{~cm}$ (Makaruk \& Sacewisz, 2011; Ramírez-Campillo, Andrade \& Izquierdo, 2013; Villarreal, González-Badillo \& Izquierdo, 2008). Villarreal, Kellis, Kraemer a Izquierdo, (2009) se v metaanalýze z 56 studií zabývají tím, jak plyometrický trénink zlepšuje vertikální výskok. Z hlediska objemu zatížení zjistili, že k významnému zlepšení dochází po dvaceti trénincích s nejméně 50 skoky v jednom tréninku.

\section{Vliv plyometrie na $\mathbf{R E}$}

Pozitivní vliv plyometrických cvičení na ekonomiku běhu popisuje studie Saunderse et al. (2006). V jejich výzkumu došlo ke zlepšení RE o 4,1 \% při rychlosti 18 km.hod. ${ }^{-1}$. Do běžného tréninku běžcům zařadili $3 \times$ týdně 30 min. plyometrická cvičení po dobu 9 týdnů. Spurrs, Murphy a Watsford (2003) také zaznamenali zlepšení RE po 6týdenním zařazení plyometrických cvičení mezi běžné běžecké tréninky. Konkrétně došlo ke zlepšení o $6,7 \%$ při rychlosti 12 km.hod. ${ }^{-1}, 6,4 \%$ při $14 \mathrm{~km}$.hod. ${ }^{-1} \mathrm{a} 4,1 \%$ při $16 \mathrm{~km}$.hod..$^{-1}$. Jelikož nedošlo ke změnám ve $\mathrm{VO}_{2}$ max, tak lze přisuzovat zlepšení právě ekonomice běhu. Berryman, Maurel a Bosquet (2010) ve své studii zjistili, že u vy- 
trvalostních běžců došlo ke snížení energetických nároků na běh vlivem plyometrických tréninků zařazených $\mathrm{k}$ těm vytrvalostním po dobu 8 týdnů. Významně se zlepšil i výkon ve vertikálním výskoku. Turner, Owings a Schwane (2003) také zaznamenali zlepšení ekonomiky běhu po 6 týdnech plyometrických tréninků zařazených k těm vytrvalostním. Ke změně $\mathrm{VO}_{2}$ max nedošlo.

Vliv plyometrického tréninku na cyklistickou ekonomiku (CE) pohybu není doposud dostatečně prozkoumán.

Primárním cílem této studie je zjistit, jaký je vliv intervenčního programu plyometrického charakteru na běžeckou a cyklistickou ekonomiku pohybu. Očekáváme pozitivní vliv plyometrické intervence na ekonomiku běhu (při rychlostech 10 a 12 km.hod..$^{-1}$ ) a ekonomiku šlapání na kole (při intenzitě 1,5 a $2 \mathrm{~W} \cdot \mathrm{kg}^{-1}$ ).

\section{METODIKA}

Výzkumný soubor tvořili zdraví muži (bez zranění pohybového aparátu v předchozím roce a půl), studenti prvního ročníku Fakulty sportovních studií Masarykovy univerzity, kteří nebyli dlouhodobě vytrvalostně trénovaní. Záměrným výběrem podle vyhodnocení dotazníků (zdravotní stav, trénovanost) jich bylo vybráno 33 a následně byli náhodným výběrem rozděleni do experimentální (EXP) a kontrolní (KON) skupiny. Výzkum dokončilo 28 testovaných osob. Z experimentální skupiny nedokončil výzkum jeden proband z důvodu nemoci (neabsolvoval alespoň $90 \%$ tréninků). Z kontrolní skupiny výzkum nedokončili 4 probandi kvůli nemoci v době závěrečného testování. Z experimentální skupiny tedy dokončilo výzkum 17 testovaných osob a $\mathrm{z}$ kontrolní 11 (Tabulka 1). Probandi potvrdili informovaný souhlas. Výzkum byl schválen etickou komisí FSpS MU.

Tab. 1: Popisné statistiky zkoumaného souboru

\begin{tabular}{|l|c|c|c|c|c|}
\hline & N platných & Průměr & Minimum & Maximum & Sm. odch. \\
\hline Věk (let) & 28 & 20,29 & 19 & 22 & 0,94 \\
\hline Výška $(\mathrm{cm})$ & 28 & 182,32 & 168 & 203 & 7,98 \\
\hline Hmotnost $(\mathrm{kg})$ & 28 & 76,98 & 58,1 & 95,2 & 10,03 \\
\hline
\end{tabular}

Dva týdny před tréninkovým programem probíhalo vstupní spiroergometrické testování pro zjištování ekonomiky pohybu (cyklistické a běžecké).

\section{Intervence}

Před každou intervenci bylo zařazeno vždy stejné rozcvičení probandů po dobu $10 \mathrm{~min}$. (5 min. jogging, 5 min. dynamický strečink velkých svalových skupin a submaximální výskoky).

Samotná intervence představovala 8 sérií po 10 opakováních cviku depth jump, tedy vertikálního výskoku po vykročení z lavičky (vysoké $40 \mathrm{~cm}$ ). Cvičenec stál na lavičce, začal vykročením jedné nohy před sebe, ve vzduchu přisunul obě chodidla vedle sebe tak, aby měkce dopadl na přední části chodidel do mírného podřepu. Ihned po dopadu se snažil co nejrychleji a co nejvýše vyskočit vzhůru. Poté následovala pauza $5 \mathrm{~s}$, během které se cvičenec vrátil do výchozí polohy na lavičku. Provedení jednoho cviku trvalo $2 \mathrm{~s}$. Po každé sérii deseti cviků následoval interval odpočinku 2 min. V závěru probandi absolvovali zklidnění aerobního charakteru nízké intenzity (cooldown) 3-4 min. Trénink trval celkem 40 min.

Testované osoby trénovaly $2 \times$ týdně po dobu 8 týdnů. Dva plyometrické tréninky týdně doporučují i např. Villarreal, González-Badillo a Izquierdo (2008). Uvádějí, že stř̌ední objem výskoků 
(60 výskoků $2 \times$ týdně po dobu 7 týdnů) je efektivnější než vysoký objem výskoků (60 výskoků $4 \times$ týdně po dobu 7 týdnů).

Testované osoby cvičily během intervenčních programů jen jeden konkrétní cvik (depth jump) tak, jak to bývá často prováděno pro vědecké účely (Koch et al., 2003; Makaruk \& Sacewicz, 2011; Walsh, Arampatzis, Schade \& Brüggemann, 2004).

Jednotlivé intervence probíhaly v tělocvičně na parketách, protože plyometrické cvičení je nezbytné vykonávat na tvrdém povrchu, aby se využil cyklus natažení a zkrácení při svalové práci (Ramírez-Campillo, Andrade \& Izquierdo, 2013).

Pro účely zjištění vlivu plyometrického cvičení na RE a CE byly použity následující standardizované nástroje:

METALYZER ${ }^{\circledR}$ 3B CORTEX Biophysik GmbH, LODE Katana běhátko a LODE Excalibur bicyklový ergometr.

\section{Výzkumná měření}

Ekonomika běhu - po rozcvičení testovaná osoba běžela $5 \mathrm{~min}$. rychlostí $10 \mathrm{~km} \cdot$ hod. $^{-1}$. Poslední 2 min. úseku se shromažd’ovala data o spotřebě kyslíku, poté se rychlost zvýšila na $12 \mathrm{~km}$. hod. $^{-1}$, opět po dobu 5 min., a data se zaznamenávala také v posledních 2 min.

Ekonomika cyklistická - po rozcvičení přešla testovaná osoba na bicyklový ergometr a začala šlapat na první úrovni zátěže, která byla stanovena výpočtem $1,5 \mathrm{~W} \cdot \mathrm{kg}^{-1}$, šlapala po dobu $5 \mathrm{~min}$., v posledních 2 min. probíhal záznam dat, poté následoval pětiminutový interval s intenzitou $2 \mathrm{~W} \cdot \mathrm{kg}^{-1}$ hmotnosti probanda a v posledních 2 min. intervalu se opět zaznamenávala spotřeba kyslíku.

\section{Statistické zpracování dat}

Statistické výpočty byly prováděny pomocí programu STATISTICA 12. Pro všechna statistická testování byla zvolena hladina významnosti $\alpha=0,05$. Normalita dat byla testována KolmogorovSmirnovovým testem. Pro statistické zpracování byla použita jednofaktorová (experimentální vs. kontrolní skupina) analýza rozptylu (ANOVA) opakovaných měření (vstupní a výstupní měření). Hodnocení signifikantnosti rozdílů mezi jednotlivými testy bylo zjištováno metodou post hoc testu (Tukeyho HSD testu).

\section{VÝSLEDKY}

Naměřené hodnoty jsou přehledně uvedeny v Tabulce 2 a grafické znázornění změn průměrných hodnot u obou skupin před a po intervenci je na Obrázku 1-4.

Tab. 2

\begin{tabular}{|c|c|c|c|c|c|}
\hline & \multicolumn{2}{|c|}{ EXP } & \multicolumn{2}{|c|}{ KON } & \multirow{2}{*}{$\mathbf{p}$} \\
\hline & PRE & POST & PRE & POST & \\
\hline běh 10 km.hod..$^{-1}\left(\mathrm{ml} \cdot \mathrm{kg}^{-1} \cdot \mathrm{min}^{-1}\right)$ & $39,53 \pm 2,63$ & $38,47 \pm 2,7$ & $37,60 \pm 2,32$ & $37,59 \pm 3,08$ & 0,322 \\
\hline běh $12 \mathrm{~km} \cdot \mathrm{hod}^{-1}\left(\mathrm{ml} \cdot \mathrm{kg}^{-1} \cdot \mathrm{min}^{-1}\right)$ & $46,50 \pm 2,77$ & $45,36 \pm 3,11$ & $44,41 \pm 2,06$ & $45,08 \pm 4,21$ & 0,122 \\
\hline kolo $1,5 \mathrm{~W} \cdot \mathrm{kg}^{-1} \quad\left(\mathrm{ml} \cdot \mathrm{kg}^{-1} \cdot \mathrm{min}^{-1}\right)$ & $29,84 \pm 2,62$ & $30,02 \pm 2,59$ & $27,94 \pm 2,01$ & $26,41 \pm 5,06$ & 0,248 \\
\hline$\left(\mathrm{ml} \cdot \mathrm{kg}^{-1} \cdot \mathrm{min} .^{-1}\right)$ & $36,40 \pm 2,97$ & $36,48 \pm 2,32$ & $34,15 \pm 1,76$ & $33,63 \pm 6,70$ & 0,724 \\
\hline
\end{tabular}

Výsledné hodnoty jsou ve formátu $\mathrm{M} \pm \mathrm{SD}$. 


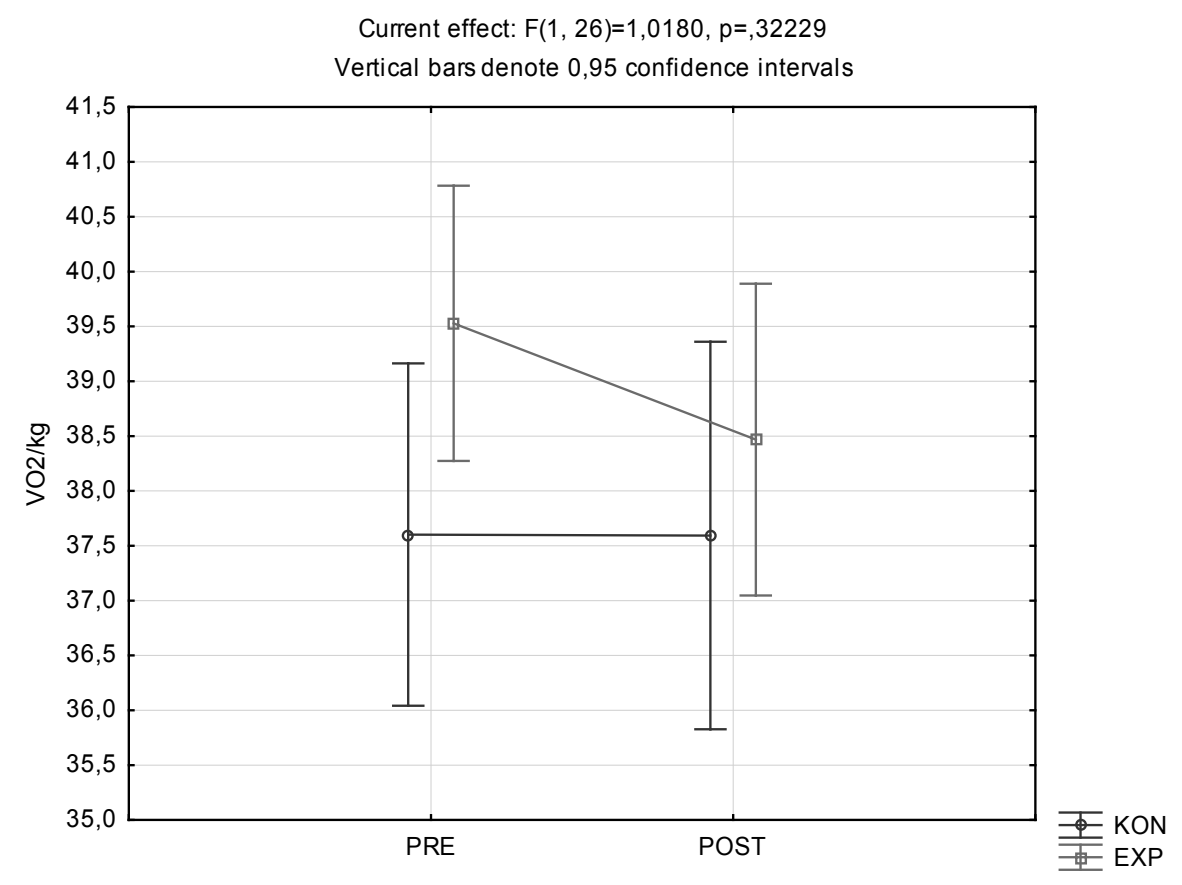

Obr. 1: Výsledky běžecké ekonomiky při rychlosti $10 \mathrm{~km} \cdot$ hod. $^{-1}$

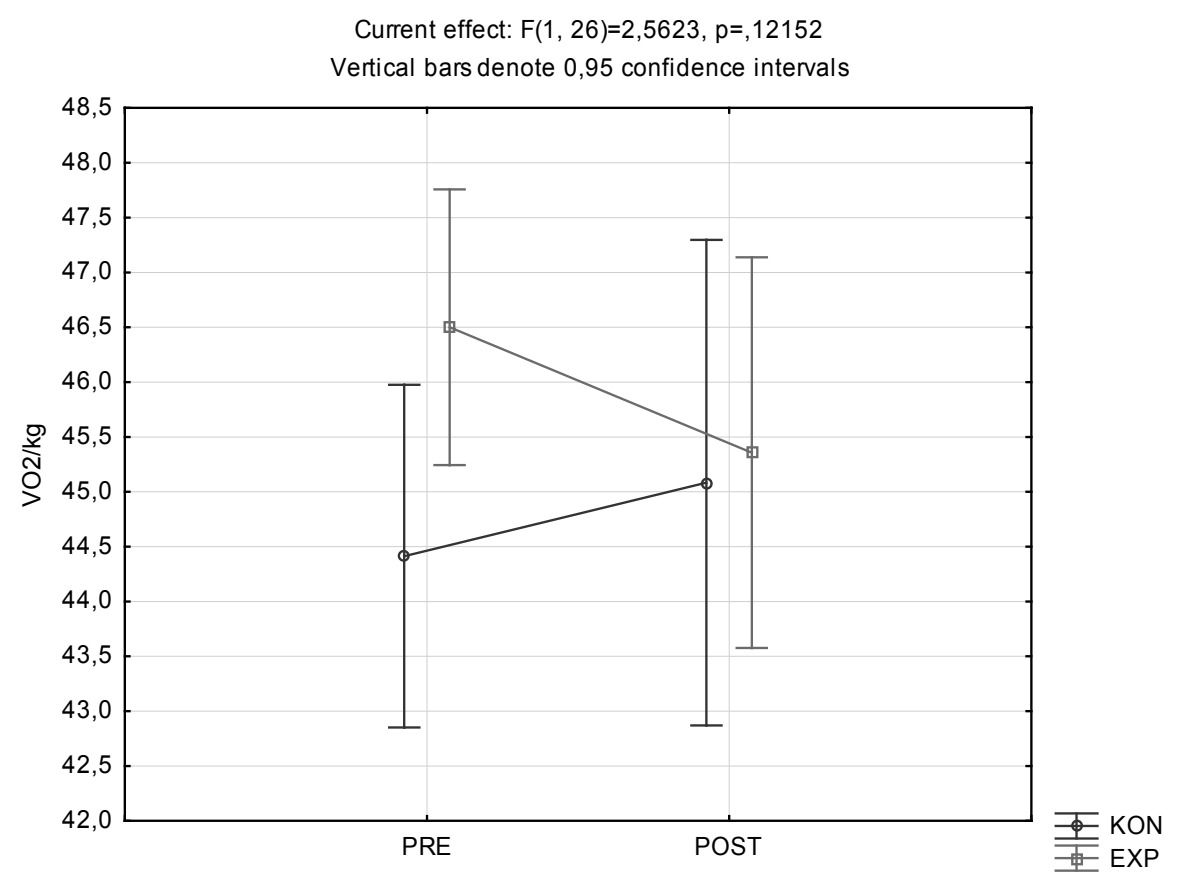

Obr. 2: Výsledky běžecké ekonomiky při rychlosti 12 km.hod. ${ }^{-1}$ 


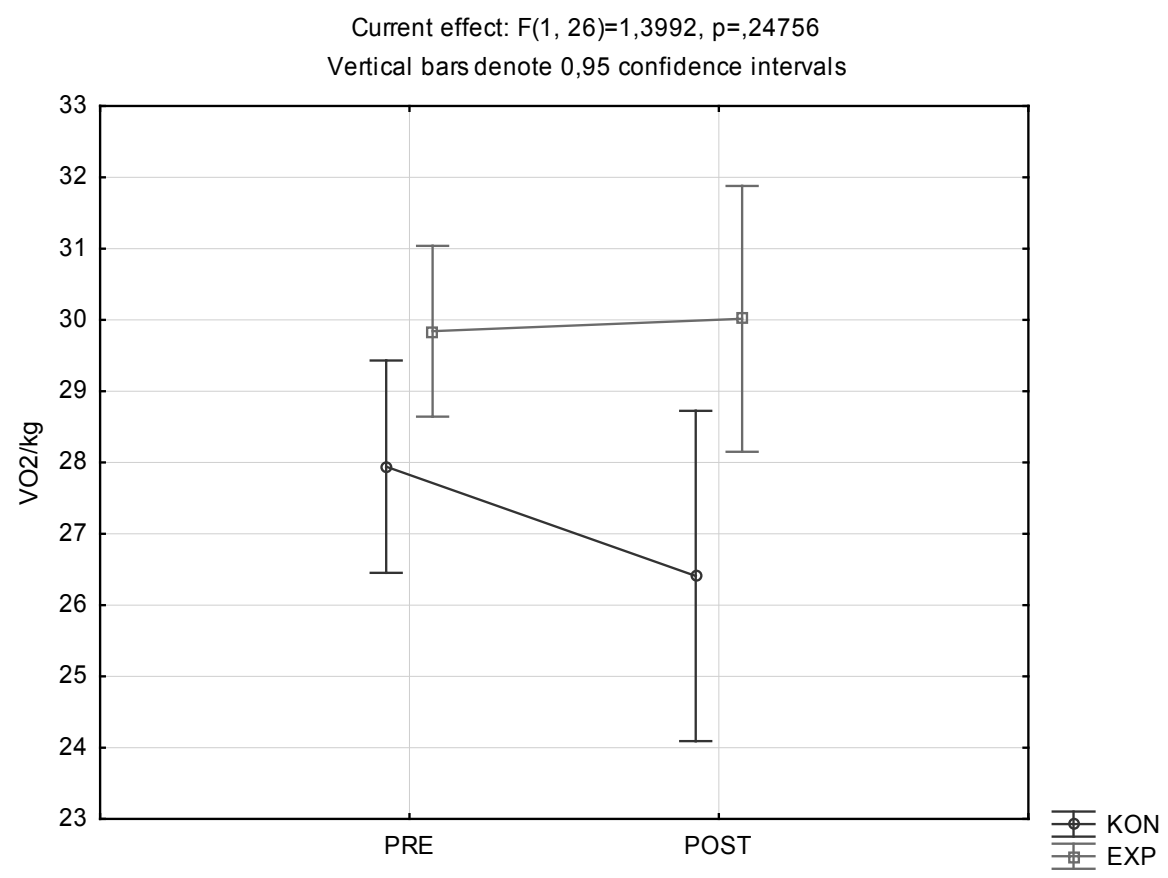

Obr. 3: Výsledky cyklistické ekonomiky při zátěži 1,5 W. $\mathrm{kg}^{-1}$

Current effect: $F(1,26)=, 12717, p=, 72426$

Vertical bars denote 0,95 confidence intervals

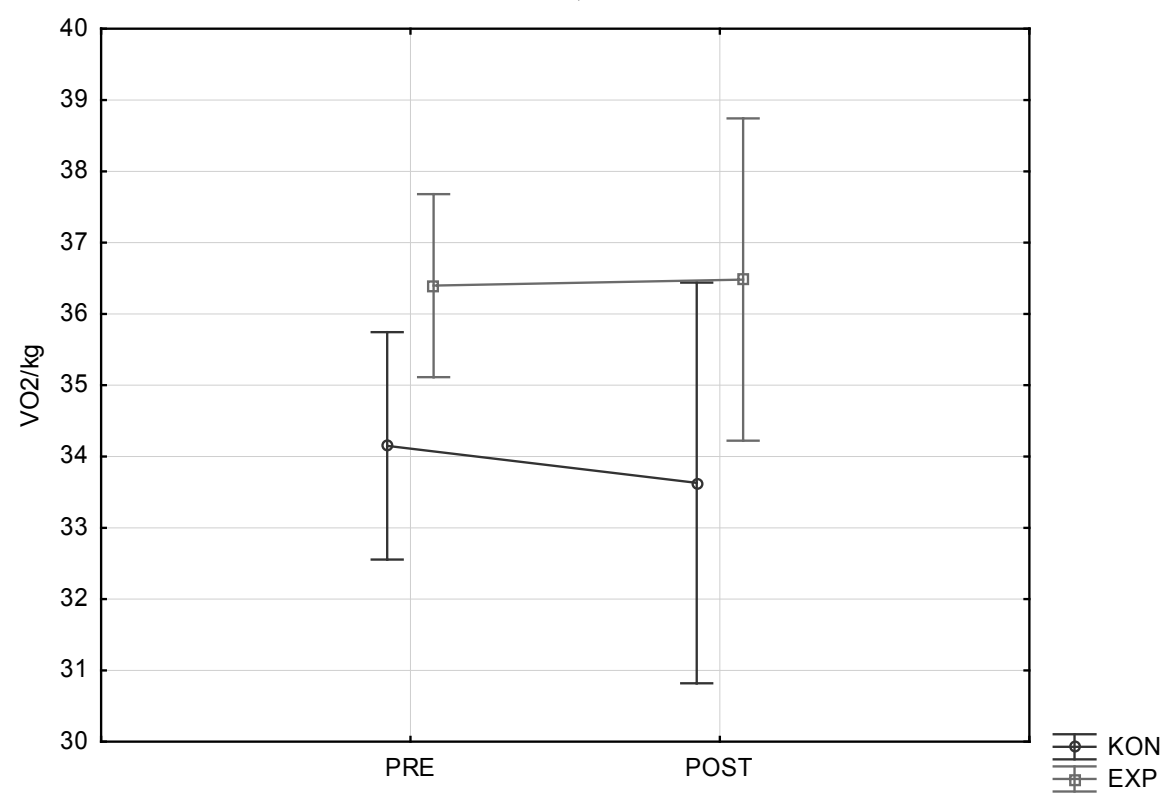

Obr. 4: Výsledky cyklistické ekonomiky při zátěži $2 \mathrm{~W} \mathrm{~kg}^{-1}$ 


\section{DISKUZE}

Primárním výstupem studie je zjištění, že realizací krátkodobého plyometrického tréninku prostřednictvím cviku depth jump nedošlo ani u experimentální ani u kontrolní skupiny k signifikantnímu zlepšení RE při rychlostech 10 a 12 km.hod.-1. Stejně tak diference mezi cyklistickou ekonomikou před plyometrickou a po plyometrické intervenci nevykazují významné rozdíly $(\mathrm{p}<0,05)$ u zátěže 1,5 respektive $2 \mathrm{~W} . \mathrm{kg}^{-1}$ na bicyklovém ergometru.

Výsledky týkající se vlivu plyometrické intervence na běžeckou ekonomiku částečně korespondují s nejednotnými závěry obdobných studií, které byly v posledních 15 letech realizovány. Např́iklad Saunders et al. (2006) prokázal u elitních běžců na dlouhé trati signifikantní zlepšení RE po aplikaci krátkodobé ( 5 a 9 týdnů) plyometrické intervence při běhu rychlostí 18 km.hod. ${ }^{-1}$. Při běhu nižšími rychlostmi ( 14 a $16 \mathrm{~km}$. hod. $^{-1}$ ) však nebylo prokázáno zlepšení RE. Domníváme se, že zásadním efektem plyometrického tréninku je zlepšená schopnost „skladovat“ a využívat elastickou energii. Tato energie však s prodlužujícím se časem kontaktu chodidla s podložkou přestává být využitelnou pro zvýšení podílu vykonané práce. S tímto faktem jsme při plánování designu studie sice kalkulovali, avšak náš výzkumný soubor zahrnoval pouze sportovce subelitní výkonnostní úrovně, u kterých nebylo reálné (z bezpečnostního i logického hlediska) kalkulovat $\mathrm{s}$ aplikací pre a posttestu na běhátku při rychlostech nad $15 \mathrm{~km} \cdot$ hod. $^{-1}$ (většina sportovců měla ANP při rychlostech běhu mezi 12-14 km.hod. ${ }^{-1}$ ). Východiskem z hlediska navržených rychlostí pro nás byla studie Spurrse, Murphyho a Watsforda (2003), která dokumentuje signifikantní zlepšení RE po šestitýdenním zařazení plyometrických cvičení při rychlosti $12 \mathrm{~km}$. hod. $^{-1}, 14$ km.hod. ${ }^{-1}$ a $16 \mathrm{~km}$. hod. $^{-1}$. Reálná čísla identifikovaná v námi realizovaných šetřeních však ukazují na nevýznamné zlepšení RE, a to přesto, že experimentální skupina vykazovala zlepšení o 2,7 respektive $2,5 \%$ při rychlostech 10 a 12 km.hod. ${ }^{-1}$. Výsledky kontrolní skupiny se nelišily v porovnání dat z pre a posttestu o 0,03 , respektive $1,5 \%$ prì rychlostech 10 a km.hod. ${ }^{-1}$.

Pokud v minulosti byla realizována řada studií popisující vliv plyometrických intervencí na RE, potom vliv plyometrie na cyklistickou ekonomiku nebyl v nám dostupné literatuře zkoumán. Jako logické se jevilo očekávat nižší než u RE, přesto signifikantní efekt plyometrie na CE. Fakta však ukazují na nevýznamné a procentuálně naprosto minimální rozdíly v pretestu a posttestu (CE se zhoršila o $0,6 \%$ při velikosti zátěž $1,5 \mathrm{~W} \cdot \mathrm{kg}^{-1}$ a o $0,2 \%$ při zátěži $\left.2 \mathrm{~W} \cdot \mathrm{kg}^{-1}\right)$. Spekulujeme, že důvodem mohl být fakt, že při plyometrickém tréninku jsou rekrutována rychlá svalová vlákna, zatímco výkon při relativně nízké zátěži $\left(1,5\right.$ a $\left.2 \mathrm{~W} . \mathrm{kg}^{-1}\right)$ vyžaduje efektivní nábor pomalých svalových vláken. Budeme-li brát v potaz, že v cyklistice hraje schopnost „uskladnit“ elastickou energii v excentrické fázi pohybu a využit ji v koncentrické fázi pohybu relativně malou roli, potom stimulace rychlých svalových vláken během plyometrické intervence mohla vést k poklesu efektivity práce.

\section{ZÁVĚRY}

Z hlediska výstupů pro praxi považujeme za zásadní zjištění (koresponduje s výsledky Saunderse et al., 2006), že námi aplikovaný plyometrický trénink nemá významný vliv na RE př̀i rychlostech běhu 10 a $12 \mathrm{~km}$. hod. $^{-1}$. Na druhou stranu je vhodné kalkulovat s výsledky studií, které ukazují na signifikantní vliv plyometrických intervencí na RE při vyšších rychlostech běhu nebo jiných designech intervence. $Z$ pohledu aplikace intervenčního činitele (depth jump) považujeme za vhodné zmínit fakt, že výsledky studie mohly být teoreticky ovlivněny mechanickou odlišností depth jumpu a běhu na běhátku popř. jízdou na cyklistickém ergometru.

Vzhledem k zjištění, že námi definovaný typ intervence nemá pozitivní vliv na CE při velikostech zátěže 1,5 a $2 \mathrm{~W} \cdot \mathrm{kg}^{-1}$, nedoporučujeme aplikaci plyometrických programů obdobného 
charakteru za účelem zvýšení specifické výkonnosti v cyklistice. Otázkou zůstává, zda nebude mít plyometrie pozitivní vliv na $\mathrm{CE}$ při vyšších intenzitách testování, a to zejména $\mathrm{v}$ př́ípadech, $k d y$ dochází i k aktivaci svalových vláken IIa, popř. IIb.

\section{Literatura}

Bassett, D. R., \& Howley, E. T. (2000). Limiting factors for maximum oxygen uptake and determinants of endurance performance. Med Sci Sports Exerc, 32, 1, 70-84.

Cacek, J., Lajkeb, P., \& Michálek, J. (2007). Trénink síly v atletice (metoda plyometrická). Atletika, 59, 3, 17-20.

Berryman, N., Maurel, D., \& Bosquet, L. (2010). Effect of Plyometric vs. Dynamic Weight Training on the Energy Cost of Running. J Strength Cond Res, 24, 7, 1818-1825.

Grasgruber, P., \& Cacek, J. (2008). Sportovní geny. Brno: Computer Press.

Kampmiller, T., et al. (2012). Teória športu a didaktika športového tréningu. Bratislava: KM Agency.

Kijowksi, K. N., et al. (2015). Short-term Resistance and Plyometric Training Improves Eccentric Phase Kinetics in Jumping. J Strength Cond Res, 29, 8, 2186-2196.

Koch, A. J., et al. (2003). Effect of warm-up on the standing broad jump in trained and untrained men and women. J Strength Cond Res, 17, 4, 710-714.

Makaruk, H., \& Sacewicz, T. (2011). The effect of drop height and body mass on drop jump intensity. Biology of Sport, 28, 1, 63.

Markovic, G., Jukic, I., Milanovic, D., \& Metikos, D. (2007). Effects of sprint and plyometric training on muscle function and athletic performance. J Strength Cond Res, 21, 2, 543-549.

Midgley, A. W., McNaughton, L. R., \& Jones, A. M. (2007). Training to enhance the physiological determinants of long-distance running performance. Sports Med, 37, 10, 857-880.

Morgan, D. W., Martin, P. E., \& Krahenbuhl, G. S. (1989). Factors affecting running economy. Sports Med, 7, 5, 310-330.

Potteiger, J., et al. (1999). Muscle Power and Fiber Characteristics Following 8 Weeks of Plyometric Training. J Strength Cond Res, 13, 3, 275-279.

Psotta, R. (2006). Fotbal: kondiční trénink. Praha: Grada.

Ramírez-Campillo, R., Andrade, D. C., \& Izquierdo, M. (2013). Effects of Plyometric Training Volume and Training Surface on Explosive Strength. J Strength Cond Res, 27, 10, 2714-2722.

Saunders, P. U., et al. (2004). Factors affecting running economy in trained distance runners. Sports med, 34, 7, 465-485.

Saunders, P. U., et al. (2006). Short-Term Plyometric Training Improves Running Economy in Highly Trained Middle and Long Distance Runners. J Strength Cond Res, 20, 4, 947-954.

Sedano, S., Matheu, A., Redondo, J. C., \& Cuadrado, G. Effects of plyometric training on explosive strength, acceleration capacity and kicking speed in young elite soccer players. J Sports Med Phys Fitness. 51, 1, 50-58.

Spurrs, R. W., Murphy, A. J., \& Watsford, M. L. (2003). The effect of plyometric training on distance running performance. J Appl Physiol, 89, 1-7.

Turner, A. M., Owings, M., \& Schwane, J. A. (2003). Improvement in running economy after 6 weeks of plyometric training. J Strength Cond Res, 17, 1, 60-67.

Villarreal, E. S., González-Badillo, J. J., \& Izquierdo, M. (2008). Low and moderate plyometric training frequency produces greater jumping and sprinting gains compared with high frequency. J Strength Cond Res, 22, 3, 715-725.

Villarreal, E. S., Kellis, E., Kraemer, W. J., \& Izquierdo, M. (2009). Determining variables of plyometric training for improving vertical jump height performance: a meta-analysis. J Strength Cond Res, 23, 2, 495-506.

Villarreal, E. S., Requena, B. \& Newton, R. U. (2010). Does plyometric training improve strength performance? A meta-analysis. J Sci Med Sport. 13, 5, 513-522.

Walsh, M., Arampatzis, A., Schade, F., \& Brüggemann, G. P. (2004). The effect of drop jump starting height and contact time on power, work performed, and moment of force. J Strength Cond Res, 18, 3, 561-566.

Wang, Y., \& Zhang, N. (2016). Effects of plyometric training on soccer players. Exp Ther Med, 12, 2, 550-554.

\section{Kontakt na autora:}

jirkabily@seznam.cz 